\title{
Predictive Value of Maternal Anemia in Cases of Fetal Growth Restriction
}

\author{
Waleed M. Tawfik ${ }^{*}$, Shaimaa R. Abdelmaksoud ${ }^{2}$ and Ghada M. Mahmoud ${ }^{3}$ \\ ${ }^{1}$ Department of Obstetrics \& Gynecology, Faculty of Medicine - Benha University. Benha, Egypt. \\ ${ }^{2}$ Lecturer in Department of pediatrics, Faculty of Medicine - Benha University. Benha, Egypt \\ ${ }^{3}$ Lecturer in Department of Clinical Pathology, Faculty of Medicine - Benha University. Benha, Egypt
}

Corresponding author: Waleed M. Tawfik, Lecturer in Department of Obstetrics \& Gynecology, Faculty of Medicine - Benha University. Benha, Egypt.

Received date: July 07, 2021; Accepted date: July 15, 2021; Published date: August 09,2021

Citation: Waleed M. Tawfik, Ali A. Bendary and Mohamed A. Elgazar, (2021) Predictive Value of Maternal Anemia in Cases of Fetal Growth Restriction. J. Obstetrics Gynecology and Reproductive Sciences 5(6) DOI:10.31579/2578-8965/089

Copyright: (C) 2021, Waleed M. Tawfik, This is an open access article distributed under the Creative Commons Attribution License, which permits unrestricted use, distribution, and reproduction in any medium, provided the original work is properly cited.

\begin{abstract}
Anemia can be defined as a state of inadequate $\mathrm{O}_{2}$ delivery to tissues due to reduction of the $\mathrm{O}_{2}$ carrying capacity of blood practically, anemia is diagnosed when there is reduction in the hemoglobin concentration or haematocrit level below normal values.

Iron deficiency anemia is a major public health problem among women of reproductive age in most of developing countries approximately $50 \%$ of pregnant women and $35 \%$ of non pregnant women are anemic.

These nutritional disorders, has profound negative effects on pregnancy outcome, health of mothers and babies.

The objective of this study: Is to evaluate the maternal anemia during pregnancy as a risk factor for fetal growth restriction.

The study was done this study conducted on 120 pregnant women. Pregnant women with inclusion criteria: Singleton pregnancy, Gestational age more than 28 week and $\mathrm{Hb}$ level less than $10 \mathrm{mg} / \mathrm{dl}$. We exclude multiple pregnancy, Gestational age less than 28 week, Hb level more than $10 \mathrm{mg} / \mathrm{dl}$ and other medical disorder with pregnancy.

The results of this study reveal the following: There was significant difference between group 1, 2, 3, 4 as regard to $\mathrm{Hb}$ level, (PCV), (MCV), (MCH), (MCHC), (Ht) and (CBC).

The restriction of fatal growth was significant lower in sever anemic patient rather than mild or moderate anemic patient

In conclusions: The result of this study shows that there was restriction of fatal growth was significantly high in sever anemic group than mild or moderate group also, incidence of low birth weight and risk of fatal morbidity or mortality was significantly high in sever anemic group than mild or moderate group.

Keywords: predictive value; maternal anemia; fetal growth
\end{abstract}

\section{Introduction}

Anemia can be defined as a state of inadequate $\mathrm{O}_{2}$ delivery to tissues due to reduction of the $\mathrm{O}_{2}$ carrying capacity of blood [1]. Physiologic anemia is well recognized during pregnancy, resulting from an expansion of maternal plasma volume that occurs to a greater degree than the pregnancy induced expansion of red cell mass [2]. Maternal anemia can also be present or develop during pregnancy because of deficiencies of essential hematinics such as iron, vitamin $B_{12}$, and folate. Such pathologic anemia can adversely affect fetal growth and development and also increases the risk of maternal morbidity and mortality mainly at delivery if postpartum hemorrhage occurs [3].

Severe anemia is common in women from resource poor countries with an estimated $75 \%$ of women having anemia. However, even in industrialized countries, anemia mainly due to iron deficiency is common, especially in less advantaged groups. The increased hernatinic requirements during normal pregnancy can. Further compound deficiency 
states and anemia in women. Correction of anemia in the antenatal period may improve maternal and fetal outcomes [4].

Several mechanisms become operable to compensate for the reduction in the $0_{2}$ carrying capacity of blood include:

Increased $\mathrm{O}_{2}$ delivery to tissues due to reduced affinity of $\mathrm{Hb}$ to $\mathrm{O}_{2}$.

Increased plasma volume to keep the total blood volume constant.Increased cardiac output. Redistribution of blood flow from less vital to more vital organs [5].

If dietary iron intake is insufficient to offset losses due to menstruation, especially in women with menorrhagia. Studies suggest that one in 10 women of reproductive age in developed countries is iron deficient, with iron deficiency anemia (IDA) present in 2-5\% [6].

Adolescent women have a higher prevalence of iron deficiency and IDA likely to reflect iron requirements for growth during this period coupied with less reliable dietary intake of iron. The iron requirement during normal pregnancy is about $1000 \mathrm{mg}$ (300mg, are active transferred to the fetus and placenta, about $200 \mathrm{mg}$, are lost through various normal routes of excretion and increase in the total volume of circulating erythrocyte needs about $500 \mathrm{mg}$ iron) [7].

So there is high incidence of iron deficiency anemia in pregnancy because many women of child-bearing age are in pre-carious iron balance and fetal iron requirement are satisfied before maternal iron needs [8].

\section{Objective of the study}

The objective of this study is to evaluate the maternal anemia during pregnancy as a risk factor for fetal growth restrictions.

\section{Patients and Methods}

This is prospeted randomied case control study. This study was done in Department of Obstetrics and Gynecology Benha university hospital. Egypt.

This study was conducted between May 2019 and March 2020.

120 Pregnant women were included in the study classified into 2 group.

GROUP 1: 30 non anemic pregnant females taken as (control group).

GROUP2: 90 anemic pregnant female sub divided into three group.

GROUP (A): 30 anemic pregnant females with mild anemia $(\mathrm{Hb}<10$ $\mathrm{mg} / \mathrm{dl})$.

GROUP (B): 30 anemic pregnant females with moderate anemia $(\mathrm{Hb}<9 \mathrm{mg} / \mathrm{dl})$.

GROUP $(\mathrm{C}): 30$ anemic pregnant females with severe anemia $(\mathrm{Hb}<8 \mathrm{mg} / \mathrm{dl})$.

\section{Inclusion criteria:}

Sure dating (reliable last menstrual period or early ultrasound dating in first trimesters).

\footnotetext{
- $\quad$ Singleton pregnancy.

- $\quad$ Gestation age above 28 weak.

- $\quad$ Hb less than $10 \mathrm{gm} / \mathrm{dL}$.
}

\section{Exclusion criteria:}

- $\quad$ Multiple pregnancies.

- $\quad$ Gestation age less than 28 weak.

- $\quad \mathrm{Hb}$ more than $10 \mathrm{gm} / \mathrm{dL}$.

- Other medical disorder with pregnancy (i.C diabetic, cardiac, renal, ante partum hemorrhage, hypertensive disorder..... etc).

Also evaluation of the newborns by Apgar scores was done.

\section{Plane of the study:}

1. Full history taking

2. Physical examination (general and abdominal).

3. Laboratory Investigations: -

\section{Nonspecific:}

Search for proteinuria, glucosuria in order to exclude patients who have other conditions rather than anemia that affect fetal growth.

\section{Specific Laboratory Search:}

Selected cases will be submitted to laboratory investigations for anemia like:

- $\quad$ Packed cell volume (PCV): normal level 36-48\%.

- $\quad$ Mean cell volume (MCV): normal level 80-100 fl.

- $\quad$ Mean cell hemoglobin (MCH): normal level (27-34) pg. 35) $\mathrm{mg} / \mathrm{dl}$

Mean cell hemoglobin concentration (MCHC): normal level (30-

Complete blood count (CBC), hemoglobin \% ( $\mathrm{Hb} \%)$ and Hematocrit (Ht) level.

\section{Ultrasonic Examinations:}

Statistical analysis: collected data was analyzed.

\section{Results}

120 Pregnant women were included in the study classified into 2 group.

GROUP 1: 30 non anemic pregnant females taken as (control group)

GROUP2: 90 anemic pregnant female sub divided into three group.

Group (a) (b). and (C): group(c) with severe anemia $(\mathrm{Hb}<8 \mathrm{mg} / \mathrm{dl})$ show more risk and complication of IUGR, IUFD, perinatal mortality and low birth weight. 


\begin{tabular}{|l|c|c|c|c|c|c|}
\hline & Control & \multicolumn{3}{|c|}{ Subdivided group } & \multirow{2}{*}{ F value } & \multirow{2}{*}{ P } \\
\cline { 3 - 6 } & group & A & B & C & & \\
\hline Age & & & & & \\
Mean \pm SD & $28.6 \pm 2.7$ & $29.2 \pm 2.8$ & $29.8 \pm 2.1$ & $29.8 \pm 1.7$ & 1.8 & 0.1 \\
Range & $21-32$ & $25-35$ & $27-34$ & $28-35$ & & \\
\hline Parity & & & & & & \\
Primigravida & $15(23.1 \%)$ & $13(20.0 \%)$ & $20(30.8 \%)$ & $17(26.2 \%)$ & $3.6^{*}$ & 0.3 \\
Multigravida & $15(27.3 \%)$ & $17(30.9 \%)$ & $10(18.2 \%)$ & $13(23.6 \%)$ & & \\
\hline BMI & & & & & & \\
Mean \pm SD & $28.1 \pm 2.3$ & $29.4 \pm 3.8$ & $28.6 \pm 2.8$ & $29.2 \pm 3.3$ & 1.1 & 0.3 \\
Range & $25-32$ & $23-35$ & $24-33$ & $22-35$ & & \\
\hline Gest. Age & & & & & & \\
Mean \pm SD & $37.03 \pm 1.2$ & $37.2 \pm 1.4$ & $36.6 \pm 1.4$ & $36.3 \pm 1.5$ & 2.8 & 0.14 \\
Range & $35-39$ & $35-39$ & $34-39$ & $34-39$ & & \\
\hline
\end{tabular}

* $\mathbf{X}^{\mathbf{2}}$ (chi-square) $\quad \mathbf{f}$ : ANOVA (analysis of variance)

There was statistically non-significant difference between anemic and non-anemic female regarding demographic characteristics.

BMI: body mass index

Gest. age: gestational age

Table (1): Demographic data of the studied group

\begin{tabular}{|c|c|c|c|c|c|c|c|c|c|c|}
\hline & \multirow{2}{*}{\multicolumn{2}{|c|}{ Control group }} & \multicolumn{6}{|c|}{ Subdivided group } & \multirow[t]{3}{*}{$\mathrm{X}^{2}$} & \multirow[t]{3}{*}{ P value } \\
\hline & & & \multicolumn{2}{|c|}{$\mathbf{A}$} & \multicolumn{2}{|c|}{ B } & \multicolumn{2}{|c|}{$\mathbf{C}$} & & \\
\hline & No & $\%$ & No & $\%$ & No & $\%$ & No & $\%$ & & \\
\hline $\begin{array}{l}\text { blood transfusion: } \\
\text { No } \\
\text { Yes } \\
\end{array}$ & $\begin{array}{c}30 \\
0 \\
\end{array}$ & $\begin{array}{c}29.7 \\
0 \\
\end{array}$ & $\begin{array}{c}29 \\
1 \\
\end{array}$ & $\begin{array}{c}28.7 \\
5.3 \\
\end{array}$ & $\begin{array}{c}27 \\
3 \\
\end{array}$ & $\begin{array}{l}26.7 \\
15.3 \\
\end{array}$ & $\begin{array}{l}15 \\
15 \\
\end{array}$ & $\begin{array}{l}14.9 \\
78.9 \\
\end{array}$ & 36.2 & 0.000 \\
\hline $\begin{array}{l}\text { Iron supplementati } \\
\text { No } \\
\text { Yes }\end{array}$ & $\begin{array}{c}6 \\
24\end{array}$ & $\begin{array}{c}7.7 \\
57.1\end{array}$ & $\begin{array}{c}22 \\
8\end{array}$ & $\begin{array}{l}28.2 \\
19.0\end{array}$ & $\begin{array}{c}24 \\
6\end{array}$ & $\begin{array}{l}30.8 \\
14.3\end{array}$ & $\begin{array}{c}26 \\
4\end{array}$ & $\begin{array}{c}33.3 \\
9.5\end{array}$ & 36.8 & 0.000 \\
\hline
\end{tabular}

There was statistically significant difference between anemic and non-anemic female regarding history of blood transfusion and iron intake.

Table (2): comparison between pregnant females regarding history of blood transfusion and iron intake:

\begin{tabular}{|c|c|c|c|c|c|c|}
\hline & \multirow{2}{*}{$\begin{array}{l}\text { Control } \\
\text { group }\end{array}$} & \multicolumn{3}{|c|}{ Subdivided group } & \multirow[t]{2}{*}{$\mathbf{F}$} & \multirow[t]{2}{*}{$P$ value } \\
\hline & & $\mathbf{A}$ & $\mathbf{B}$ & $\mathbf{C}$ & & \\
\hline $\begin{array}{l}\text { Hb\% } \\
\text { Mean } \pm \text { SD } \\
\text { Range }\end{array}$ & $\begin{array}{c}11.5 \pm 0.5 \\
11-12 \\
\end{array}$ & $\begin{array}{c}9.5 \pm 0.5 \\
9-10 \\
\end{array}$ & $\begin{array}{c}7.7 \pm 0.5 \\
8-9 \\
\end{array}$ & $\begin{array}{c}7.5 \pm 0.5 \\
\geq 8\end{array}$ & 10.2 & 0.000 \\
\hline $\begin{array}{l}\text { PCV } \\
\text { Mean } \pm \text { SD } \\
\text { Range }\end{array}$ & $\begin{array}{c}36.9 \pm 0.5 \\
36-37.7\end{array}$ & $\begin{array}{c}34.6 \pm 0.7 \\
33-35\end{array}$ & $\begin{array}{c}31.9 \pm 0.3 \\
31-32\end{array}$ & $\begin{array}{c}30.7 \pm 0.5 \\
30-31\end{array}$ & 8.9 & 0.000 \\
\hline $\begin{array}{l}\text { MCV } \\
\text { Mean } \pm \text { SD } \\
\text { Range }\end{array}$ & $\begin{array}{c}86.6 \pm 3.1 \\
80-90\end{array}$ & $\begin{array}{c}74.6 \pm 0.5 \\
74-75\end{array}$ & $\begin{array}{c}70.2 \pm 1.9 \\
69-80\end{array}$ & $\begin{array}{c}69.6 \pm 0.6 \\
68-70\end{array}$ & 5.4 & 0.000 \\
\hline $\begin{array}{l}\text { MCH } \\
\text { Mean } \pm \text { SD } \\
\text { Range }\end{array}$ & $\begin{array}{c}32.5 \pm 0.5 \\
32-33\end{array}$ & $\begin{array}{c}25.8 \pm 0.6 \\
24-27\end{array}$ & $\begin{array}{c}24.8 \pm 0.5 \\
23-25\end{array}$ & $\begin{array}{c}24.7 \pm 0.5 \\
24-25\end{array}$ & 14.5 & 0.000 \\
\hline $\begin{array}{l}\text { MCHC } \\
\text { Mean } \pm \text { SD } \\
\text { Range }\end{array}$ & $\begin{array}{c}29.9 \pm 0.2 \\
29.3-30.2\end{array}$ & $\begin{array}{c}28.7 \pm 0.5 \\
28-29\end{array}$ & $\begin{array}{c}26.7 \pm 0.6 \\
25-27\end{array}$ & $\begin{array}{c}26.7 \pm 0.4 \\
26-27\end{array}$ & 36.3 & 0.000 \\
\hline
\end{tabular}

There was statistically significant difference between anemic and non-anemic female regarding complete blood count (CBC).

PCV: Packed cell volume

MCV: Mean cell volume

MCHC: Mean cell hemoglobin concentration

MCH: Mean cell hemoglobin

HB: hemoglobin 


\begin{tabular}{|c|c|c|c|c|c|c|c|c|c|c|}
\hline & \multirow{2}{*}{\multicolumn{2}{|c|}{ Control group }} & \multicolumn{6}{|c|}{ Subdivided group } & \multirow[t]{3}{*}{$\mathbf{X}^{2}$} & \multirow[t]{3}{*}{$P$ value } \\
\hline & & & \multicolumn{2}{|c|}{$\mathbf{A}$} & \multicolumn{2}{|c|}{ B } & \multicolumn{2}{|c|}{$\mathrm{C}$} & & \\
\hline & No & $\%$ & No & $\%$ & No & $\%$ & No & $\%$ & & \\
\hline $\begin{array}{l}\text { Preterm labor: } \\
\text { No } \\
\text { Yes }\end{array}$ & $\begin{array}{c}29 \\
1\end{array}$ & $\begin{array}{c}28.2 \\
5.9\end{array}$ & $\begin{array}{c}27 \\
3 \\
\end{array}$ & $\begin{array}{l}26.2 \\
17.6 \\
\end{array}$ & $\begin{array}{c}26 \\
4\end{array}$ & $\begin{array}{l}25.2 \\
23.5\end{array}$ & $\begin{array}{c}21 \\
9\end{array}$ & $\begin{array}{l}20.4 \\
52.9\end{array}$ & 9.5 & 0.02 \\
\hline $\begin{array}{l}\text { Postpartum } \\
\text { hemorrhage: } \\
\text { No } \\
\text { Yes }\end{array}$ & $\begin{array}{c}28 \\
2 \\
\end{array}$ & $\begin{array}{c}29.2 \\
8.3\end{array}$ & $\begin{array}{c}26 \\
4 \\
\end{array}$ & $\begin{array}{l}27.1 \\
16.7 \\
\end{array}$ & $\begin{array}{c}24 \\
6\end{array}$ & $\begin{array}{l}25.0 \\
25.0\end{array}$ & $\begin{array}{l}18 \\
12 \\
\end{array}$ & $\begin{array}{l}18.8 \\
50.0 \\
\end{array}$ & 11.7 & 0.009 \\
\hline
\end{tabular}

There was statistically significant difference between anemic and non-anemic female regarding labor related maternal complications. Table (4): labor related maternal complications

\begin{tabular}{|l|c|c|c|c|c|c|}
\hline & Control & \multicolumn{3}{|c|}{ Subdivided group } & \multirow{2}{*}{ F } & P value \\
\cline { 3 - 6 } & group & A & B & C & & \\
\hline BPD & & & & & \\
Mean \pm SD & $91.5 \pm 5.5$ & $90.1 \pm 2.9$ & $77.5 \pm 3.5$ & $76.3 \pm 2.6$ & 171.5 & 0.000 \\
Range & $82-99$ & $80-96$ & $69-83$ & $69-79$ & & \\
\hline FL & & & & & & \\
Mean \pm SD & $73.6 \pm 4.5$ & $70.7 \pm 3.9$ & $62.9 \pm 2.7$ & $61.8 \pm 1.1$ & 104.3 & 0.000 \\
Range & $67-85$ & $61-78$ & $60-68$ & $60-65$ & & \\
\hline HC & & & & & & \\
Mean \pm SD & $32.6 \pm 2.6$ & $32.4 \pm 1.3$ & $32 \pm 0.3$ & $31.2 \pm 0.4$ & 5.4 & 0.002 \\
Range & $21.3-35.9$ & $30-35$ & $31.3-32.5$ & $30.2-32$ & & \\
\hline EFW & & & & & & \\
Mean \pm SD & $3276.1 \pm 240.6$ & $3230.7 \pm 241.4$ & $2704.4 \pm 225.3$ & $2332.1 \pm 116.1$ & 135.4 & 0.000 \\
Range & $2835-3760$ & $2661-3760$ & $2050-2576$ & $2050-3847$ & & \\
\hline
\end{tabular}

There was statistically significant difference between anemic and non-anemic female regarding fetal biometry.

BPD: bi partial diameter

FL: femur length

HC: head circumference.

EFW: estimated fetal weight

Table (5): ultrasound fetal biometry in anemic and control group.

\begin{tabular}{|c|c|c|c|c|c|c|c|c|c|c|}
\hline & \multirow{2}{*}{\multicolumn{2}{|c|}{ Control group }} & \multicolumn{6}{|c|}{ Subdivided group } & \multirow[t]{3}{*}{$X^{2}$} & \multirow[t]{3}{*}{ P value } \\
\hline & & & \multicolumn{2}{|c|}{$\mathbf{A}$} & \multicolumn{2}{|c|}{ B } & \multicolumn{2}{|c|}{ C } & & \\
\hline & No & $\%$ & No & $\%$ & No & $\%$ & No & $\%$ & & \\
\hline $\begin{array}{l}\text { Premature birth } \\
\text { No } \\
\text { Yes } \\
\end{array}$ & $\begin{array}{c}30 \\
0 \\
\end{array}$ & $\begin{array}{c}28.0 \\
0.0 \\
\end{array}$ & $\begin{array}{c}28 \\
2 \\
\end{array}$ & $\begin{array}{l}26.2 \\
15.4 \\
\end{array}$ & $\begin{array}{c}26 \\
4 \\
\end{array}$ & $\begin{array}{l}24.3 \\
30.8 \\
\end{array}$ & $\begin{array}{c}23 \\
7 \\
\end{array}$ & $\begin{array}{l}21.5 \\
53.8\end{array}$ & 9.2 & 0.03 \\
\hline $\begin{array}{l}\text { Intrauterine fetal death } \\
\text { No } \\
\text { Yes } \\
\end{array}$ & $\begin{array}{c}30 \\
0 \\
\end{array}$ & $\begin{array}{c}28.0 \\
0.0 \\
\end{array}$ & $\begin{array}{c}28 \\
2 \\
\end{array}$ & $\begin{array}{l}26.2 \\
15.4 \\
\end{array}$ & $\begin{array}{c}24 \\
6 \\
\end{array}$ & $\begin{array}{l}22.4 \\
46.2 \\
\end{array}$ & $\begin{array}{c}25 \\
5 \\
\end{array}$ & $\begin{array}{l}23.4 \\
38.5 \\
\end{array}$ & 7.9 & 0.04 \\
\hline $\begin{array}{l}\text { Perinatal mortality: } \\
\text { No } \\
\text { Yes }\end{array}$ & $\begin{array}{c}30 \\
0 \\
\end{array}$ & $\begin{array}{c}27.0 \\
0.0 \\
\end{array}$ & $\begin{array}{c}29 \\
1 \\
\end{array}$ & $\begin{array}{l}26.1 \\
11.1 \\
\end{array}$ & $\begin{array}{c}27 \\
3 \\
\end{array}$ & $\begin{array}{l}24.3 \\
33.3 \\
\end{array}$ & $\begin{array}{c}25 \\
5 \\
\end{array}$ & $\begin{array}{l}22.5 \\
55.6 \\
\end{array}$ & 7.1 & 0.07 \\
\hline $\begin{array}{l}\text { Low birth weight: } \\
\text { No } \\
\text { Yes }\end{array}$ & $\begin{array}{c}30 \\
0 \\
\end{array}$ & $\begin{array}{c}34.1 \\
0.0 \\
\end{array}$ & $\begin{array}{c}30 \\
0 \\
\end{array}$ & $\begin{array}{c}34.1 \\
0.0 \\
\end{array}$ & $\begin{array}{c}26 \\
4 \\
\end{array}$ & $\begin{array}{l}29.5 \\
12.5 \\
\end{array}$ & $\begin{array}{c}2 \\
28 \\
\end{array}$ & $\begin{array}{c}2.3 \\
87.5 \\
\end{array}$ & 92.7 & 0.000 \\
\hline $\begin{array}{l}\text { Low Apgar at } 1 \text { min: } \\
\text { No } \\
\text { Yes }\end{array}$ & $\begin{array}{c}30 \\
0 \\
\end{array}$ & $\begin{array}{c}26.5 \\
0.0 \\
\end{array}$ & $\begin{array}{c}29 \\
1 \\
\end{array}$ & $\begin{array}{l}25.7 \\
14.3 \\
\end{array}$ & $\begin{array}{c}28 \\
2 \\
\end{array}$ & $\begin{array}{l}24.8 \\
28.6 \\
\end{array}$ & $\begin{array}{c}26 \\
4 \\
\end{array}$ & $\begin{array}{l}23.0 \\
57.1 \\
\end{array}$ & 5.3 & 0.2 \\
\hline $\begin{array}{l}\text { Low Apgar at } 5 \text { min: } \\
\text { No } \\
\text { Yes }\end{array}$ & $\begin{array}{c}30 \\
0 \\
\end{array}$ & $\begin{array}{c}26.8 \\
0.0 \\
\end{array}$ & $\begin{array}{c}29 \\
1 \\
\end{array}$ & $\begin{array}{l}25.9 \\
12.5 \\
\end{array}$ & $\begin{array}{c}28 \\
2\end{array}$ & $\begin{array}{l}25.0 \\
25.0\end{array}$ & $\begin{array}{c}25 \\
5 \\
\end{array}$ & $\begin{array}{r}22.3 \\
62.5 \\
\end{array}$ & 7.5 & 0.05 \\
\hline
\end{tabular}

There was statistically significant difference between anemic and non-anemic female regarding prenatal outcome. 


\begin{tabular}{|c|c|c|c|c|c|c|c|c|c|c|}
\hline & \multirow{2}{*}{\multicolumn{2}{|c|}{ Control group }} & \multicolumn{6}{|c|}{ Subdivided group } & \multirow[t]{3}{*}{$\mathrm{X}^{2}$} & \multirow[t]{3}{*}{$P$ value } \\
\hline & & & \multicolumn{2}{|c|}{$\mathbf{A}$} & \multicolumn{2}{|c|}{ B } & \multicolumn{2}{|c|}{$\bar{C}$} & & \\
\hline & No & $\%$ & No & $\%$ & No & $\%$ & No & $\%$ & & \\
\hline $\begin{array}{l}\text { IUGR: } \\
\text { No }\end{array}$ & 30 & 100.0 & 25 & 83.3 & 18 & 60.0 & 15 & 50.0 & 23.5 & 0.000 \\
\hline Yes & 0 & 0.0 & 5 & 16.7 & 12 & 40.0 & 15 & 50.0 & & \\
\hline
\end{tabular}

There was statistically significant difference between anemic and non-anemic female regarding prevalence of intrauterine growth retardation (IUGR). Table (7): prevalence of intrauterine growth retardation (IUGR) among pregnant anemic and non-anemic females:

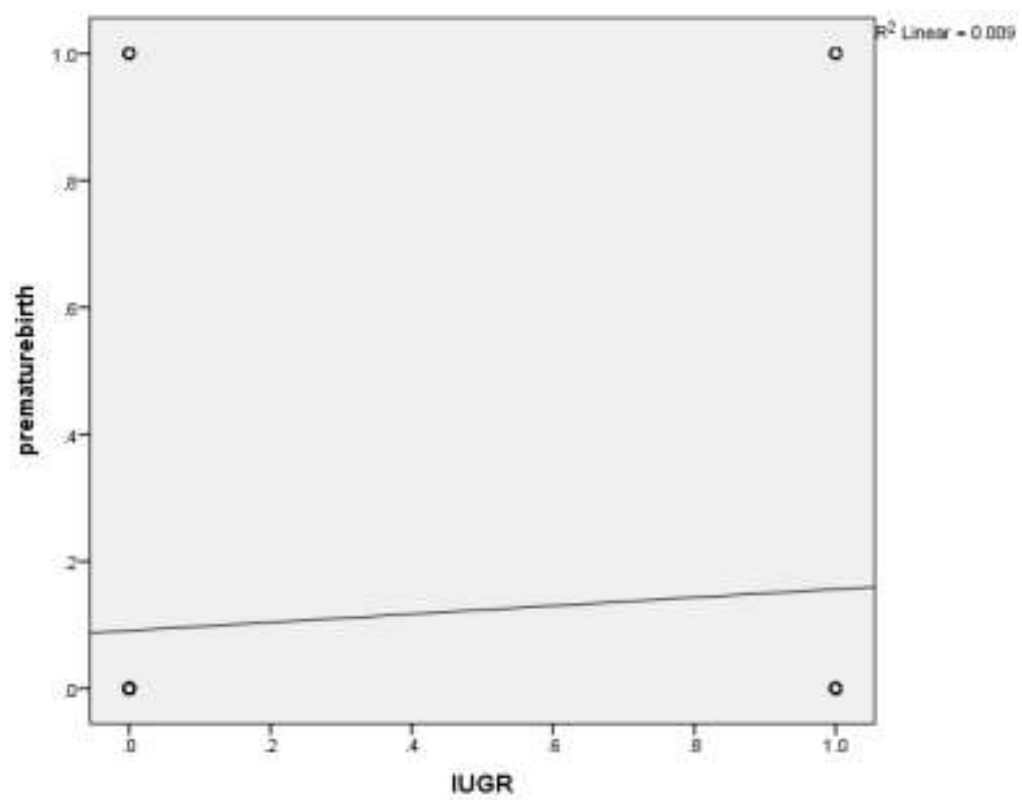

Fig. (7): correlation between IUGR in pregnant females and fetal outcome

\begin{tabular}{|l|l|l|l|l|l|}
\hline \multicolumn{1}{|c|}{ Parameter } & Sensitivity \% & Specificity \% & Accuracy \% & PPV\% & NPV\% \\
\hline Premature birth & 14.4 & 100 & 35.8 & 100 & 71.9 \\
\hline Intrauterine fetal death & 14.4 & 100 & 35.8 & 100 & 71.9 \\
\hline Perinatal mortality & 10 & 100 & 32.5 & 100 & 72.9 \\
\hline Low birth weight & 35.6 & 100 & 51.7 & 100 & 65.9 \\
\hline Low Apgar at 1 min & 7.7 & 100 & 30.8 & 100 & 73.5 \\
\hline Low Apgar at 5 min: & 8.9 & 100 & 31.7 & 100 & 73.2 \\
\hline IUGR & 35.6 & 100 & 51.7 & 100 & 65.9 \\
\hline
\end{tabular}

Table (8): Specificity, sensitivity and accuracy of anemia as a predictor to pregnancy outcome complications:

\section{Discussion}

Anemia in pregnancy is an important and in this study preventable cause of maternal and fetal morbidity and mortality. A high prevalence of anemia has been observed in this study. Majority of women had moderate anemia while mild and sever show less percentage. The most common cause of anemia in pregnant women was iron deficiency [9].

Anemia may be related to poor dietary habits or inadequate iron supplementation during pregnancy as well as grand multiparty. Mothers often embark on pregnancy with low iron and other nutritional stores through the combined effect of inadequate nutrition and repeated pregnancy and lactation during their child bearing years.

The presumed mechanism of anemia in multiparous mothers is chronic exhaustion of iron stores and other haemopoietic factors due to repeated loss to the fetus during pregnancy and to the neonate during lactation [10]. In this study Maternal mortality among anemic women is five times more than non anemic women as anemic women are less likely to with stand obstetric hemorrhage, obstetric shock and trauma of difficult and complicated labor and infection which badly handled women have gone through. High cardiac output failure is likely when hemoglobin of the patient is $7 \mathrm{gm}$ or less specially in cases of pre eclampsia and hypertension [11].

Overweight and obese women had a same risk of anemia in this study [12].

In this study increased number of gravidity is a contributing factor for anemia in pregnancy. However, our observation is similar to the finding. [13].

In this study Correlating anemia and gestational age stated that the risk of preterm delivery increase with the intensity of anemia [9].

In this study high prevalence of anemia detected in 3rd trimester could be due to maximum demand of micronutrients in this time period combined with already existing iron deficiency in our socioeconomic setup because majority of patients in this area belong to poor 
socioeconomic class and also majority of women have their first antenatal visit when they are reaching term. Same results have been observed in another study [11].

In this study Post-partum hemorrhage was more common in our anemic women compared with non-anemic women. Although the difference was not significant, labor in anemic women may be associated with postpartum hemorrhage similar to other reports in different study [14].

This complication in this study has more serious squeal in anemic women including cardiovascular instability and the need for blood transfusion with its inherent risks. Routine active management of the third stage of labor in anemic pregnant patients is, therefore, recommended to reduce the incidence and adverse hemodynamic effects of post-partum hemorrhage [15].

In this study Effects of maternal anemia on fetus with mild and moderate anemia harmful effects may not be seen immediately. There may be certain learning and behavioral problems as the child grow up. Severe anemia in mother with hemoglobin seven grams per $100 \mathrm{ml}$ is associated with preterm labor and still birth. Fetus being a to takes up essential iron from maternal circulation during its development and about $350 \mathrm{mg}$ in total gestation and most of the time born with a cord blood hemoglobin of (12-14) grams at birth During subsequent development in extra uterine life the iron deficiency may occur as breast milk is a poor source of iron hence neonatal anemia is common if not taken care of .this agree in other studies [16].

This study reported hemoglobin levels during the third trimester had erratic consequences regarding birth weight. Importantly, the odds ratios for small-for-gestational-age babies were lower when hemoglobin concentrations were low-normal or low during the second and third trimesters than among women whose hemoglobin concentrations were above $12 \mathrm{~g} / \mathrm{L}$. These data emphasis the fact that the iron nutritional and hematological status in the first and second trimesters are the ones that have an influence in the outcome of pregnancy, rather than the status at term or at the third trimester. It would appear that the normal haemodilution reaching a nadir during the second and early third trimester of pregnancy favors the uneventful course of pregnancy and fetal growth and well being, resulting in normal new born.

This study disagree with other which found no significant difference in APGAR score in between the study groups [9]. APGAR score was higher in control group as compared to anemic group. shows a higher APGAR score in control as which compared to mild and moderate anemic groups . This signifies the status of well being of the fetus in anemic and normal condition of the mother.

In this study Correct diagnosis and treatment lead to effective management of fetal and maternal risks and improved prenatal outcome. While new such as hypo chromic red cells and - parameter transferring receptors enable correct differential diagnosis and therapy monitoring, new therapeutic options such as iron sucrose complex improve therapy effectiveness and safe outcome avoiding blood transfusion. Future investigation of iron metabolism in pregnancy should put an eye on such as a possible hypo ferric anemia in pregnancy which was usually falsely regarded as pure iron deficiency anemia in pregnancy [17].

In this study Poor we observed compliance with oral therapy because of digestive side effects which can lead to worsening of anemia. In these cases parenteral forms of administration are indicated as well as in those patients in whom oral treatment is ineffective like in those suffering from inflammatory bowel disease many of whom are iron deficient and show digestive intolerance to ferrous salt Intravenous iron therapy was found safe, and more effective than intramuscular iron [18].

\section{Conclusion}

The result of this study show that there was restriction of fatal growth was significantly high in sever anemic group than mild or moderate group also, incidence of low birth weight and risk of fatal morbidity or mortality was significantly high in sever anemic group than mild or moderate group.

\section{References}

1. AardemaM et al (2012) Uterine artery Doppler flow and uteroplacental vascular pathology in normal pregnancy and pregnancies complicated by preeclampsia and small for gestational age fetuses. Placenta; 22:405.

2. Ahlbom H.E.; Simple achlorhydric anemia, Br. Med.j.; 1:332, 1936 Quoted from Williams Hematology (2013).

3. Beard JL. (2017) Effectiveness and strategics of iron supplementation during pregnancy. Am J Clin Nutr 7I:1288S-94S.

4. Bender DA and Bender AE (2014): Iron. In, Nutrition a reference hand book. Chapter 24.P394-405.

5. Bothwell TH (2016): Iron requirements in pregnancy and strategies to meet them. Am J Clin Nutr 72:257S-64S

6. Breukers RM, Sepehrkhouy S, and Spiegelenberg SR et al (2017): Cardiac output measured by a new arterial pressure waveform analysis method without calibration compared with thermodilution after cardiac surgery. J Cardiothorac Vasc Anesth 21: 632-635.

7. Cheng, Y., Zak, O., Aisen, P., Harrison, S.C.and Walz, T. (2014): Structure of the human transferrin receptor-transferrin complex. Cell 116, 565-576.

8. Cook JD., Flowers CH., Skikne BS (2013): The quantitative assessment of body iron. Blood 101:3359-3364.

9. Thangaleeta SC, Gilmore A. (2010): The role of hydroxyurea in the management of sickle cell disease. Blood Rev; 17:99-109.

10. Dim BH and Anath (2018): Diagnostic advances in defining erythropoietic abnormalities and red blood cell diseases. Sem. Hematol. 38: 148.

11. Awan MM GL (2011): Hemostatic changes associated with normal and abnormal pregnancies. Clin Lab Sci 13: 223-228.

12. Bonder JV and Lewis SM (2016): Practical haematology, Edited by $\mathrm{S}$ Mitchell Lewis: Ninth edition, Basic haematological techniques chapter 20, P.20-24.

13. Loo G., Wong E.and Means RT (2012): Hepcidin inhibits in vitro erythroid colony formation at reduced erythropoietin concentrations. Blood 107(7):2702-4.

14. Frenetic PS, Atweh GF.: Sickle cell disease: old discoveries, new concepts, and future promises. J Clin Invest (2017); 117:850-8.

15. Galloway MJ, Rushworth L.: Red cell or serum folate? Results from the National Pathology Alliance benchmarking review. J ClinPathol (2013); 56:924-6.

16. Gupta N et al: (2013)The incidence, risk factors and obstetric outcome in primigravid women sustaining anal sphincter tears. Acta Obstet GynecolScand 82:736.

17. Perewusnyk, G., Huch, R., Huch, A., and Breymann, C. (2014) parenteral iron therapy in obstetrics: 8 year experience with iron sucrose-complex. Br. J. Nutr. $88,10-3$.

18. Wali A, Mushtaq A, Nilofer : (2012)Comparative study efficacy, safety and compliance of intravenous iron sucrose and intramuscular iron sorbitol in iron deficiency anemia of pregnancy. J Pak Med Assoc;52:392-5. 